\title{
The paradoxical nexus between corporate social responsibility and sustainable financial performance: evidence from the international construction business
}

Article

Accepted Version

Lu, W., Ye, M., Chau, K. W. and Flanagan, R. (2018) The paradoxical nexus between corporate social responsibility and sustainable financial performance: evidence from the international construction business. Corporate Social Responsibility and Environmental Management, 25 (5). pp. 844-852. ISSN 1535-3958 doi:

https://doi.org/10.1002/csr.1501 Available at https://centaur.reading.ac.uk/76635/

It is advisable to refer to the publisher's version if you intend to cite from the work. See Guidance on citing.

To link to this article DOI: http://dx.doi.org/10.1002/csr.1501

Publisher: Wiley

All outputs in CentAUR are protected by Intellectual Property Rights law, including copyright law. Copyright and IPR is retained by the creators or other copyright holders. Terms and conditions for use of this material are defined in the End User Agreement. 


\section{www.reading.ac.uk/centaur}

\section{CentAUR}

Central Archive at the University of Reading

Reading's research outputs online 


\title{
The paradoxical nexus between corporate social responsibility and sustainable financial performance: evidence from the international construction business
}

\author{
Weisheng $\mathrm{Lu}^{1}$, Meng $\mathrm{Ye}^{2 *}, \mathrm{~K} . \mathrm{W}$. Chau ${ }^{3}$ and Roger Flanagan ${ }^{4}$
}

\begin{abstract}
The aim of the research is to substantiate the hypothesis of a paradoxical dynamic link between corporate social responsibility (CSR) and its material implications including sustainable corporate financial performance (CFP). By analysing a panel of sixty-seven international construction companies from 2006 to 2015, we found out that CSR programs can be detrimental to CFP in the short term but conducive to improving it in the long term. The findings of this research present that in the international construction business, the impact of CSR on CFP is not immediate and unchanging, and it takes time to materialise CSR for sustainable development. A significant practical use of this research is to provide evidence for the assertion that business stakeholders should be relieved from short-termism in assuming social responsibility. Further research is recommended to test this support in a more general business setting towards developing a general theory on CSR and sustainable development.
\end{abstract}

Keywords: Corporate social responsibility, corporate financial performance, sustainable development, stakeholder management, international construction

\footnotetext{
${ }^{1}$ Associate Professor, Dept. of Real Estate and Construction, Faculty of Architecture, The University of Hong Kong, Pokfulam, Hong Kong.

${ }^{2} \mathrm{PhD}$ Candidate, Dept. of Real Estate and Construction, Faculty of Architecture, The University of Hong Kong, Pokfulam, Hong Kong (corresponding author). E-mail: megan828@ connect.hku.hk, Tel: +852 67044695

${ }^{3}$ Chair Professor, Dept. of Real Estate and Construction, Faculty of Architecture, The University of Hong Kong, Pokfulam, Hong Kong.

${ }^{4}$ Professor, School of Construction Management and Engineering, The University of Reading, Reading, UK.
} 


\section{Introduction}

Corporate social responsibility (CSR) is a contentious subject in academia and the business world. There is no consensus on what it actually means. It is generally agreed that Bowen (1953) coined the modern phrase of CSR, although the intellectual debate of CSR can be dated back to the late 1930s (e.g. Barnard, 1938; Clark, 1939; Kreps, 1940). Central to this debate is whether corporations should assume the responsibility of society, given the existence of a clear, de-facto boundary between them. Friedman (1970) famously argued that "...there is one and only one social responsibility of business - to use its resources and engage in activities designed to increase its profits so long as it stays within the rules of the game ...". Using his characteristically influential language, Friedman further argued that if managers used corporate resources for any cause other than profit maximisation, it would constitute a form of theft (Snell, 2000).

Kitson and Campbell (1996), among other researchers, were critical of Friedman's extreme view. CSR gained momentum in academia with the vogue of systems thinking (Arnold and Wade, 2015) and stakeholder theory (Green, 2009; Boesso et al, 2015; Schons and Steinmeier, 2016). Porter and Kramer (2006; 2011) advocated "creating shared value" (CSV) - creation of economic value for a business in such a way that also creates value for society. Although the views of Friedman and Porter appear to be antithetical, they are actually not that far apart since both positions emphasise profitability as the basis of a business. To date, most researchers and managers tend to adopt an eclectic position, accepting that businesses have an obligation to assume social responsibilities when pursuing commercial profit (Lu et al., 2014). This eclectic position reflects changes in the social and political climate worldwide, indicated by the decline of laissez-faire, the increase of government intervention, the acceptance of stakeholder theory, the deepening of globalisation, and the emergence of sustainable development (Green, 2009). 
CSR has emerged as "an inescapable priority for business leaders in every country" (Porter and Kramer, 2006, p.78). This is evident from numerous statistics, anecdotal narratives, and international standards or guidelines (e.g. ISO 26000 of the International Standard Organisation; Guidelines for Multinational Enterprises of the Organisation for Economic Cooperation and Development; and the CSR reporting guidelines of the Global Reporting Initiative). However, business executives are sometimes criticised for being hesitant or myopic in their assumption of social responsibility, paying mere lip service to CSR or seeing it as simply window-dressing (Painter-Morland, 2006). In a competitive business world there needs to be genuine economic grounds for implementing CSR (DTI, 2002); without evident benefits for companies, CSR may not continue to flourish since CSR programmes are costly and constantly competing for a firm's scarce resources (Wang et al., 2008).

To establish its legitimacy, researchers have sought to provide 'business cases' for CSR programs. The oft-cited business cases of pursuing CSR include: reduced cost and risk, strengthened reputation, increased attractiveness of the firm to prospective employees (Carroll and Shabana, 2010), competitive advantages (Porter and Kramer, 2006), crisis recovery (Vallaster, 2017) and sustainable development (Lawal et al, 2017). Researchers have also sought to find an empirical link between CSR and corporate financial performance (CFP), a link that has been widely debated amongst management theorists and business executives. Critical reviews of these studies can be found in Margolis and Walsh (2001), Orlitzky et al. (2003), and Lu et al. (2014). Most of the studies report a positive relationship between CSR and CFP, while some show a non-significant or a negative relationship. Generally, the CSRCFP nexus research appears to be stuck in a dichotomy of 'allies-and-adversaries', whereby the CSR-CFP nexus is assumed as either negatively or positively correlated.

Gradually, researchers have recognised that the CSR-CFP relationship is not static but a dynamic process changing over time. Wagner (2009), for example, analysed the time effect 
on the CSR-CFP relationship, while Inoue and Lee (2011) revealed the impacts of CSR on CFP in terms of short-term profitability and future market evaluation. While it is not new that contemporary researchers have acknowledged the CSR-CFP relationships in either short or long term, there has been no attempt to integrate the two into a refined theoretical view capable of accounting for their paradoxical dynamics.

The primary aim of this paper is thus to offer and test a refined proposition on the dynamic and sophisticated relationship between CSR and CFP by considering time lags. The overarching hypothesis is that a paradoxical link exists between CSR and CFP: CSR is detrimental to CFP in the short term but will be conducive to CFP in the long term. This hypothesis will be tested in an international construction setting. Probably no industry offers as many paradoxes as construction CSR (Lu et al., 2015). On the one hand, construction has an inherent social responsibility through its important contribution to the national economy, providing a large number of jobs, and materialising the built environment that is fundamental to support our social and economic activities; on the other hand, construction is intrinsically irresponsible for considerable negative impacts on the natural environment and ethically responsible for its poor occupational health and safety record. Since CSR travels with international construction companies (ICCs) to various countries with different socioeconomic backgrounds, international construction market provides a revealing lens through which the paradoxes can be examined on a global scale. Furthermore, examining CSR in the specific context of international construction rather than in a general setting follows the advocacy for localised industry-specific CSR (Ward and Smith, 2011; Porter and Kramer, 2006).

The remainder of this paper is structured as follows: Section 2 provides a theoretical foundation for this research; based on which, Section 3 describes the context of international construction business and develops the hypothesis that the short-term effect of CSR is a 
negative CFP, whereas the long-term effect of CSR is a higher CFP. Two sets of data, CSR and CFP data are described in Section 4, in which we also describe the measures for testing the hypothesis and the steps to apply the Vector Error Correction Model (VECM). In Section 5, we present the results of the test, whereby we confirm the hypothesis. Section 6 discusses the results, draws conclusions and reflects on the limitations of this research.

\section{Theoretical foundation}

The intellectual debate over CSR is often framed within neoclassical economics (Donaldson and Fafaliou, 2003). A company is established for the express purpose of making profits is one of the basic assumptions on which neoclassical economics rests (Weintraub, 2007). Theorists, in particular the proponents of contractarian theory, assert that shareholders can legitimately be considered the owners of a firm (e.g., Hart, 1996; Mikami, 2011). Despite the 'agency conflicts' problem between business owners and executives (Hansmann and Kraakman, 2001), the latter should be loyal to the owners and have a binding fiduciary duty to meet their interests. A corporation is not society so why should it assume the responsibilities that belong to society. It is against this broad backdrop that Friedman (1970) made his famous statement that "the business of business is business". Another school of neoclassic thought, represented by Coase (1937; 1960) and Williamson (1991) among others, proposed the transaction cost theory, whereby production is organised within firms (e.g. through hierarchy) when the transaction cost of coordinating production through the market is greater. The implication is that if CSR adds to the transaction cost, it should be disconnected from a firm's fiduciary responsibilities. In either the 'corporate-society' or the 'firm-market' view, there is a clear, de-facto boundary between a corporation and its external environment (e.g. society, market, or external stakeholders).

However, as the neoclassic views relating to CSR evolved during the period from the 1960s to the 1980s when 'systems think' and 'stakeholder theory' came into vogue (Green, 
2009), businesses became increasingly conceptualised as open systems that engage in a dynamic interaction with the broader environment (Lawrence and Lorsch, 1967). It is now broadly accepted that companies do not operate in a vacuum but that through their stakeholders they impact and are impacted by the socio-political context within which they operate. According to Freeman (1984) a stakeholder is anybody who can affect or is affected by a system. For modern companies, stakeholders may include both internal stakeholders (such as owners, customers, employees, and suppliers) and external stakeholders (such as governmental authorities, competitors, environmentalists, the public, and the media) (Schons and Steinmeier, 2016). There is a 'social contract' between a company and society (Mathews, 1993; Deegan, 2002) such that firms agree to perform in a socially responsible way in return for societal approval, which ultimately guarantees their continued existence (Deegan, 2002; Brown and Deegan, 1998). As a result of these evolvements, the traditional boundary between a firm and its outside environment has become blurred. CSR has become a key business driver that inevitably influences companies' strategic priorities (Murray and Dainty, 2008). Porter and Kramer $(2006 ; 2011)$ even advocated shifting societal issues from the periphery to the core of a business.

The dilemma, however, is that firms should assume social responsibilities, while they are founded and legally bound based on the traditional doctrine of maximising profits for shareholders. CSR programmes compete for a firm's scarce resources such as capital, entrepreneurship, manpower, time, and management effort. When the firm's benefits (providing it stays within the rules of the game) cannot align with society's, where is the borderline to be drawn? Under the dual pressures from corporation and society, it would be unsurprising if business executives are at times hesitating or even short-sighted to fully engage in CSR. Margolis and Walsh (2003) also charged that the lack of normative theories describing the impact of companies on society makes it difficult for managers to make decisions as to 
what extent they should be involved in CSR. With due respect to proponents of CSR who focus on a firm's moral obligations, theorists, in particular the instrumentalists, have tried to find the evidence to demonstrate that CSR will ultimately bring the corporation higher financial performance.

\section{Hypotheses development}

When in the setting of international construction business, CSR issues become more paradoxical and can be meaningfully examined. International construction is defined by Ngowi et al. (2005) as the part of construction business that is undertaken by companies working on projects outside their home country. Construction materialises the built environment, which influences human health, economic activities, social behaviour, cultural identity, and civic pride (Pearce, 2003), on the one hand; On the other hand, construction has been particularly slow in embracing CSR, with fierce competition, substandard work, low pay, and poor health and safety standards. However, CSR is growing in prominence as a core issue confronting the construction industry and its organisations (Murray and Dainty, 2008). Various researchers, such as Jones et al. (2006), Jones et al. (2010), Bowen et al. (2007), and Petrovic-Lazarevic (2008), have reported CSR issues in the construction industry of South Africa, the UK, the U.S., and Australia. The Global Reporting Institute even published construction and real estate sector-specific guidelines on CSR reporting in 2013.

Implementation of CSR programs in construction, as in any business, consumes valuable corporate resources. For example, although the call for green buildings is becoming more insistent, they require more advanced and inevitably costlier materials, facilities, technologies, and human resources (Lu and Yuan, 2013). Implementation of policies and programs, such as a group-wide code of ethics that addresses bribery, formal training for employees, and the inclusion of sub-contractors in oversight mechanisms, requires not only investment of cash and capital, but also human resources, and even involves changes to 
operational modes. Construction companies are often involved in costly CSR activities related to the local community, such as providing free education or other philanthropic efforts, or assisting host countries with infrastructure construction such as roads, bridges, or hospitals. Therefore, with the inevitable cost involving in the CSR activities, the financial performance would be affected. This forms the first hypothesis that: $H_{1}$ : The link between CSR and CFP in the short term is negative.

At the same time, CSR activities can be a means of gaining benefits for construction business. Companies with well-developed procurement regulations and clear policies can more easily gain a competitive advantage; particularly in the presence of complex processes and supply chains. In addition, employee training in safety, ethics and technology usually guarantees working efficiency, leading to better outcomes and the attraction of better employees; collectively, amongst the most valuable of corporate resources. CSR also assists with site occupational health and safety issues (Lu et al., 2015), and controlling costs by helping reduce the internal costs of accidents (MSCI, 2015). The award of construction contracts is nowadays based on not only cost and ability, but also safety and environmental protection considerations. CSR enhances the competitiveness of construction companies and helps establish organisational reputation. Especially in the international construction market, CSR itself has become a strongly institutionalized feature of the contemporary corporate landscape and itself is kind of way to gain legitimacy (Jackson and Apostolakou, 2010). By achieving legitimacy or gaining reputation, companies can reduce the cost of doing business abroad (Zaheer, 2002), as well as increase the firm's probability of winning bids (Hillebrandt and Cannon, 1989). Moreover, construction companies with high CSR reputation ratings may enjoy improved relations with bankers and investors, facilitating their access to capital and decreasing financial risks (Orlizky et al., 2003). However, the potential benefits of implementing CSR 
programs may not be cultivated immediately. It takes time to materialise CSR. Therefore, the second hypothesis is: H2: The link between CSR and CFP in the long term is positive.

In summary, the overarching hypothesis is a paradoxical link exists between CSR and CFP. It is proposed that the short-term effect of CSR is a negative CFP, whereas the long-term effect of CSR is a higher CFP. The paradoxical relationship between CSR and CFP hypothesised in this paper differs from the curvilinear (U-shaped) or inversely U-shaped curve between CSR and CFP explored in the literature (e.g. Barnett and Salomon, 2006; Wang et al., 2016). Although they recognise the basic issue of whether the costs of social responsibility are offset or exceeded by financial returns over a period of time, they treated firm-year observations as independent of time, without considering the lead-lag effects. To substantiate this hypothesis will provide fresh answer to the question regarding the disputed CSR-CFP link, and will help divert researchers' attention away from the 'allies-and-adversaries' dichotomy towards the paradoxical dynamics between CSR and CFP. In addressing the time factor, our hypothesis supports executives' need for time to cultivate the benefits of resources spent on CSR programs. It will link current CSR efforts with good management theory to encourage more of a focus on discretionary management that will ultimately turn costly CSR into higher CFP.

\section{Methods}

\subsection{Data and samples}

Two sets of data were collected for analysis and testing: CSR and CFP data. The initial sample was based on the firms included in the CSR database: the MSCI Environmental, Social and Governance (ESG) Intangible Value Assessment (IVA) indices. The indices developed by the MSCI are for research and ratings of corporate management of environmental, social risk factors, and other CSR activities. Based on the Global Industry Classification Standard developed by the MSCI, construction-related industries were identified, including the 
construction and engineering industry, the construction materials industry, and the construction and farm machinery industry. ICCs were then identified accordingly from the index lists. The data set covers 10 years (2006-2015). Not all the ICCs were included in the lists every year. To allow for longitudinal analysis, ICCs incorporated in the lists over a period of more than 5 continuous years were selected as the sample.

All the ICCs included in the IVA indices are publicly listed companies which are required to reveal financial data to the public. Therefore, CFP data could be extracted from their annual reports or databases such as Bloomberg.com and Capital IQ. All the financial data are standardised and reported in U.S. dollar. The final usable sample was a panel of 67 ICCs from 2006 to 2015, comprising firms from 21 countries including the U.S., Australia, Japan, Southern Korea, China, Singapore and European countries. Table 1 is an excerpt of the panel data.

$<<$ Table 1: An excerpt of the panel data $>>$

\subsection{Measures}

\subsubsection{Independent variable}

Applying the IVA indices mentioned above, a firm's CSR performance is rated based on environmental, social, and governance pillars. The MSCI considers carbon emissions, toxic emissions and waste, and opportunities for clean technology as the key environmental issues. For the social pillar, corruption and instability, and health and safety, are regarded as the key issues. Key governance indicators include audit, board structure, shareholder rights, compensation, and transparency. The weights of key issues are set according to the industry's relative contribution to the externality of each issue, as well as the time frame for internalisation of these costs. Each year firms receive a weighted average CSR score ranging from 0 to 10 based largely on investments in the three pillars. In this research, the weighted average CSR scores are treated as the measurement for the independent variable -CSR. 


\subsubsection{Dependent variable}

Orlitzky et al. (2003) listed various CFP measures, finding widely used profitability measures to include ROA, ROE, profit margin, EPS, and sales growth rate, and then converging these measures into three broad subdivisions: market-based (investor returns), accounting-based (accounting returns) and perceptual (survey). In this research, following the suggestion of Lu et al. (2014) that more objective CFP measures be used (depending on data availability, and considering stock market fluctuation), we adopted the accounting-based indicator -the growth of revenue as the dependent variable (McGuire, 1988; Lopez et al., 2007), which could be represented by the natural logarithm of revenue.

\subsubsection{Control variables}

We choose factors which have significant effects on the performance as the control variables:

Firm size. It is measured by using a natural logarithm of firm market capitalisation (Moeller et al., 2004; Cahan et al., 2015).

Capital structure. Capital structure is measured by the debt/equity ratio (Lu and Beamish, 2004; Chao and Kumar, 2010). It can reveal financing preferences as well as being a measure of a firm's risk.

National level control variables. Given the differences among the sampled ICCs doing business in different institutional environments, which could also be a critical factor for CSR activities, World Bank nation-level institutional measures were selected as a control for 'country of origin' (Cahan et al., 2015; De Villiers and Marques, 2015; Wang et al., 2016).

Industry dummy variables. Since there are three construction-related industries in the sample, we create two dummy variables for industries to eliminate the effects of sub-industries.

Dummy variables for year 2008 and 2009. We create two dummy variables for year 2008 and year 2009 to indicate the effects of the 2008-2009 financial crisis.

\subsection{The steps of Panel Vector Error Correction Model (VECM)}


According to Engle and Granger (1987), two first-difference $(I(1))$ series are said to be cointegrated if there exists linear combination of the two which produces a stationary trend. When the two series show the co-integrated relationship, they may be unequal in the short term, but they are tied together in the long run (Granger, 1981). It is suggested by Engle and Granger (1987) that a generating mechanism called the 'Error Correction Model (ECM)' could test the co-integrated relationship, which forces the variables to move closely together over time while allowing a wide range of short-term dynamics.

$\underline{\text { Step } 1}$ is to test the stationarity of the variables, a process to ensure that the mean, variance and autocorrelation structure do not change over time. Two series should in the same level, e.g. both are $I(1)$, for the further test. Stationarity of the variables is tested by a unit root test for all series. In this research, the null hypothesis of a unit root using the Augmented Dickey-Fuller (ADF) test was conducted. With lag length selected as zero, each series was tested for the presence of a unit root.

$\underline{\text { Step } 2}$ is to do the co-integration test to indicate the long-term relations between the CSR and CFP (indicated by nature logarithm of revenue-LnREV) series. Fisher Johansen trace tests for co-integration were applied in a stepwise. The empirical model for this test is based on the following equation:

$$
\begin{gathered}
\operatorname{LnREV}_{\mathrm{it}}=\beta_{0}+\mathrm{CSR}_{\mathrm{it}} \times \beta_{1}+\mathrm{C}_{\mathrm{it}} \times \gamma+\mu_{\mathrm{it}} \\
\mathrm{C}_{\mathrm{it}} \times \gamma=D E_{i t} \times \gamma_{1}+\text { FirmSize }_{i t} \times \gamma_{2}+\sum \text { NationLevel }_{i j} \times \gamma_{3 j}+\text { Industry } \times \gamma_{4} \\
+{\text { TimeEffect }(08) \times \gamma_{5}+\text { TimeEffect }_{(09)} \times \gamma_{6}}^{\text {Timef) }}
\end{gathered}
$$

where the subscript $i$ indicates individual firm, $t$ represents the time, $\operatorname{LnREV}_{\text {it }}$ is the dependent variable- nature logarithm of revenue, $\mathrm{CSR}_{\mathrm{it}}$ is the independent variable- $\mathrm{CSR}, \mathrm{C}_{\mathrm{it}}$ is the control variable (e.g. D/E ratio, firm size indicated by the nature logarithm of market capitalization, national level control variables, industry dummy variables and dummy variable 
for year 2008 and 2009, explained in equation (2)), $\beta_{1}$ and $\gamma$ are the coefficients of $\operatorname{CSR}_{i t}$ and $\mathrm{C}_{\mathrm{it}}, \beta_{0}$ is the constant term, and $\mu_{\mathrm{it}}$ is labelled as an error term.

$\underline{\text { Step } 3}$ is to apply VECM (Vector Error Correction Model) in order to further evaluate the short run properties of the co-integrated series, if co-integration has been detected between series (tested in Step 2). Granger causality test is used to establish causal links between variables and short-term Granger causalities are determined by the Wald test for significance of the coefficients of the series (Asari et al., 2011; Pala, 2013). Here, ECM is true in the case of a single equation while in the VECM there is a system of equations. The first-order error correction model is shown:

$$
\Delta \mathrm{LnREV}_{\mathrm{it}}=\Delta \mathrm{CSR}_{\mathrm{it}-1} \times \beta_{1}-\rho\left(\mathrm{LnREV}_{\mathrm{it}-1}-\alpha_{0}-\mathrm{CSR}_{\mathrm{it}-1} \times \alpha_{1}\right)+\mathrm{C}_{\mathrm{it}} \times \gamma+\mu_{\mathrm{it}}
$$

where the subscript $i$ indicates individual firm, $t$ represents the time, $\Delta \operatorname{LnREV}_{\mathrm{it}}$ and $\Delta \mathrm{CSR}_{\mathrm{it}-1}$ are the first-difference operators of the dependent variable, one-year lag of the independent variable, $C_{i t}$ is the control variable, $\beta_{1}, \gamma$, and $\alpha_{1}$ are the coefficients of $\Delta \operatorname{CSR}_{\mathrm{it}-1}, \mathrm{C}_{\mathrm{it}}$, and $\mathrm{CSR}_{\mathrm{it}-1}$, and $\mu_{\mathrm{it}}$ is the serially uncorrelated error term. $\operatorname{LnREV}_{\mathrm{it}-1}-\alpha_{0}-\mathrm{CSR}_{\mathrm{it}-1} \times \alpha_{1}$ is called error correction term (ECT), and $\rho$ is the coefficient of the error correction term. So, equation (3) can be shown as follows:

$$
\Delta \mathrm{LnREV}_{\text {it }}=\Delta \mathrm{CSR}_{\mathrm{it}} \times \beta_{1}-\rho \times \mathrm{ECT}+\mathrm{C}_{\mathrm{it}} \times \gamma+\mu_{\mathrm{it}}
$$

where ECT is short for error correction term $\left(\operatorname{LnREV}_{\mathrm{it}-1}-\alpha_{0}-\mathrm{CSR}_{\mathrm{it}-1} \times \alpha_{1}\right)$. In equations (1), (3), and (4), the parameter $\rho=1-\sigma$.

\section{Results and analyses}

\subsection{Stationary test}


The results in Table 2 show that the ADF test with the method of none, constant and trend is used in the level and the first difference for the dependent variable and independent variable respectively. As both the categories of variables are not stationary in the level while first differencing the variables being stationary, they could be tested for co-integration to see if there is some linear combination of the two that produces a stationary trend (Engle and Granger, 1987).

$<<$ Table 2: ADF unit root test $\gg>$

\subsection{Johansen test for co-integration}

Results of the Johansen panel co-integration test are reported in Table 3. First differencing of CSR and LnREV series have a long-term relationship at the 1\% significant level (i.e. 99\% confidence level), indicating that there exist long-term relationships between the CSR and CFP series.

$<<$ Table 3: Johansen test for co-integration $>>$

\subsection{Granger causality test by Vector Error Correction Model (VECM)}

As the variables are co-integrated, the VECM (Vector Error Correction Model) was adopted to test the dynamic relationship between CSR and CFP. The Wald test explains the short-term causality between CSR and CFP, while the statistics provided by the lagged error correction terms explain the intensity of the long-term causality effects. Results of the VECM and Wald statistic tests are shown in Table 4.

$<<$ Table 4: Granger Causality Test by Vector Error Correction Model $>>$ 
As a result of the VECM test in the first differencing series, Wald statistic (3.3379) for CSR is statistically significant at the $10 \%$ level. This implies that CSR in the short term affects the increase of revenue. The adjustment parameter in the LnREV ECT (-0.0947) is statistically significant, suggesting that in the long term, CSR Granger-causes increase in revenue. The adjustment coefficient of ECT indicates an adjustment to the long-term equilibrium with an estimated value of 0.0947 .

\subsection{Short-term and long-term equilibrium between CSR and CFP}

The coefficient of $\Delta \mathrm{CSR}_{\mathrm{it}-1}$ and the coefficient of one period lag error correction term (ECT) represent the equilibrium position in the short and long run, respectively. The estimated values of these parameters are given in Table 5 .

$<<$ Table 5: Short and long run equilibrium $>>$

The estimated value of the coefficient of $\Delta \mathrm{CSR}_{\mathrm{it}-1}$ is -0.0238 , which is significant at the $10 \%$ level. This coefficient represents the short-term equilibrium. The results of the Wald test shown in Table 4 indicate the significant short-term temporary negative impacts of CSR on CFP. This supports $\mathrm{H}_{1}$ : The link between CSR and CFP in the short term is negative. While ECT restores variables (CSR and LnREV) back to equilibrium or corrects disequilibrium, its sign should be a significant negative. As shown in Table 5, the coefficient is negative (-0.0947) and is significant at $1 \%$ level, suggesting that, in the long term, CSR performance Grangercauses LnREV. The adjustment coefficients for ECT indicate that the system adjusts its previous period's disequilibrium at a speed of $9.47 \%$ annually. Thus, $\mathrm{H}_{2}$ is supported: The link between CSR and CFP in the long term is positive.

\section{Discussions and conclusions}


In this research, the positive, negative and neutral links between CSR and CFP were integrated into a fresh view to describe their paradoxical dynamics. ICCs harness CSR as a form of 'soft power' to achieve market penetration, and in the long run, sustainable development. Focusing on the international construction business, we find that implementing CSR programmes is slightly detrimental to CFP in the short term but will benefit CFP in the long term. This offers a fresh perspective to the long-standing debate on the CSR-CFP link. With the introduction of time into the dynamics, the traditional dichotomous views on the CSR-CFP relationships as being either positive or negative can now be conceived of as complementary rather than unchanging and conflicting, and pointing towards a theory of paradoxical CSR-CFP dynamics.

The classic discussions of firm boundaries can also be enriched through this research. Theories of the firm assert that certain economic tasks, if added to the transaction cost, should be excluded from the boundary of a firm and be performed by the market (Coase, 1937, 1960; Williamson, 1991). Given that CSR consumes firm's resources, many scholars believe that CSR should be excluded from the boundary of a firm. Some have misunderstood Friedman (1970), assuming he was against CSR when he famously argued that socially desirable goals, if at the expense of profitability, should be disconnected from a company's fiduciary responsibilities. This research shows that, with discretionary management, CSR could reduce transaction costs and ultimately bring a higher financial performance to the company. This could be achieved, for example, through development of a harmonious relationship with stakeholders so as to guarantee key resources, or by developing a reputation to secure sufficient construction contracts. It follows that business stakeholders should not vacillate over whether to conduct CSR or not, but should rather focus on how to properly manage CSR as an ally of CFP in line with good management practice.

A significant practical use of this research is to provide evidence for the assertion that business stakeholders should be relieved from short-termism when they launch CSR 
programmes. Most contemporary companies are established and governed according to traditional theories that stress profit maximisation and where shareholders' profits are protected by law while equally important stakeholders' benefits are bound only by social contracts. In a competitive business world, company executives are perpetually burdened with having to justify their CSR strategies with higher CFP. However, it is suggested that not only may CSR not immediately lead to higher financial performance but that it may actually result in a negative impact on a firm's financial performance in the short term. Shareholders should therefore take a long-term view when looking at executives' CSR strategies.

Despite its contributions, this research also has limitations. Firstly, it was undertaken in a confined, construction-related business sector. Future research is encouraged to test the hypothetical paradoxical link between CSR and CFP in a more general setting so that the results can be generalized, or even utilized to ultimately develop a theory. Secondly, although the paradoxical link between CSR and CFP has been confirmed using statistical methods, when and how CSR programs will become allies of CFP remains unclear. Future research is recommended to discover empirical evidence to articulate the 'epistemological link' for stakeholders to manage CSR programs that lead to positive CFP and sustainability in the long term. Thirdly, use of the panel VECM model method does not allow precise definition of the 'long' or 'short' term. Further research is recommended to apply other statistical methods to find the time frame in which CSR investments make a return, thereby helping managers to enhance their discretionary judgment.

\section{References}

Arnold, R.D., Wade, J.P., 2015. A definition of systems thinking: a systems approach. Procedia computer science, 44, 669-678. DOI: 10.1016/j.procs.2015.03.050.

Asari, F.F.A.H., Baharuddin, N.S., Jusoh, N., Mohamad, Z., Shamsudin, N., Jusoff, K., 2011. A vector error correction model (VECM) approach in explaining the relationship between 
interest rate and inflation towards exchange rate volatility in Malaysia. World applied sciences journal, 12(3), 49-56.

Barnard, C.I. 1938. The functions of the executive. Harvard University Press; Cambridge, MA.

Barnett, M.L., Salomon, R. M. 2006. Beyond dichotomy: The curvilinear relationship between social responsibility and financial performance. Strategic management journal, 27(11), 1101-1122. DOI: 10.1002/smj.557

Boesso, G., Favotto, F., Michelon, G., 2015. Stakeholder prioritization, strategic corporate social responsibility and company performance: further evidence. Corporate social responsibility and environmental management, 22(6), 424-440. DOI: 10.1002/csr.1356

Bowen, P., Akintoye, A., Pearl, R., Edwards, P.J. 2007. Ethical behaviour in the South African construction industry. Construction management and economics, 25(6), 631-648. DOI: $10.1080 / 01446190701225707$

Brown, N., Deegan, C. 1998. The public disclosure of environmental performance information - a dual test of media agenda setting theory and legitimacy theory, Accounting and business research, 29(1), 21-42. DOI: 10.1080/00014788.1998.9729564

Cahan, S.F., De Villiers, C., Jeter, D.C., Naiker, V., Van Staden, C.J., 2015. Are CSR disclosures value relevant? Cross-country evidence. European accounting review, 1-33. DOI: $10.1080 / 09638180.2015 .1064009$

Carroll, A.B., Shabana, K.M. 2010. The business case for corporate social responsibility: A review of concepts, research and practice. International journal of management reviews, 12(1), 85-105. DOI: 10.1111/j.1468-2370.2009.00275.x

Chao, M. C.-H., Kumar, V. 2009. The impact of institutional distance on the international diversity-performance relationship. Journal of world business, 45, 93-103. DOI: 10.1016/j.jwb.2009.04.005

Clark, J.M., 1939. Social control of business. New York: McGraw-Hill. 
Coase, R. 1937. The nature of the firm. Economica, 4(16), 386-405. DOI: $10.1093 / 0198297807.003 .0003$

Coase, R. 1960. The Problem of Social Cost. Journal of law and economics, 3, 1-40. DOI: $10.1086 / 674872$

De Villiers, C., Marques, A. 2015. Corporate social responsibility, country-level predispositions, and the consequences of choosing a level of disclosure. Accounting and business research, 46(2), 167-195. DOI: 10.1080/00014788.2015.1039476

Deegan, C. 2002. Introduction: the legitimising effect of social and environmental disclosuresa theoretical foundation. Accounting, auditing \& accountability journal, 15, 282-311. DOI: $10.1108 / 09513570210435852$

Donaldson, J., Fafaliou, I. 2003. Business ethics, corporate social responsibility and corporate governance: a review and summary critique. European research studies, 6(1/2), 90-110.

Engle, R.F., Granger, C.W. 1987. Co-integration and error correction: Representation, estimation, and testing. Econometrica, 251-276. DOI: 10.2307/1913236

Freeman, R.E. 1984. Strategic management: a stakeholder approach, Boston: Pitman.

Friedman, M. 1970. The social responsibility of business is to increase its profits. New York Times Magazine, 13, 32-33.

Granger, C.W., 1981. Some properties of time series data and their use in econometric model specification. Journal of econometrics, 16(1), 121-130. DOI: 10.1016/03044076(81)90079-8

Green, S. 2009. The evolution of corporate social responsibility in construction: Defining the parameters. In Corporate social responsibility in the construction industry, Murray, M. and Dainty, A. (eds). Taylor \& Francis: London; 24-53.

Hansmann, H., R. Kraakman. 2001. The End of History of Corporate Law. Georgetown law journal, 89, 439-468. 
Hart, O.D. 1996. The Meaning of Ownership. In Wealth creation and wealth sharing, M. M. Blair (eds). Washington: Brookings Institution Press; 25-32.

Hillebrandt, P.M., Cannon, J., 1989. The management of construction firms: aspects of theory. Intl Specialized Book Service Inc.

Inoue, Y., Lee, S. 2011. Effects of different dimensions of corporate social responsibility on corporate financial performance in tourism-related industries. Tourism management. 32(4), 790-804. DOI: 10.1016/j.tourman.2010.06.019

Jackson, G., Apostolakou, A., 2010. Corporate social responsibility in Western Europe: an institutional mirror or substitute?. Journal of business ethics, 94(3), pp.371-394. DOI: $10.1007 / \mathrm{s} 10551-009-0269-8$

Jones, P., Comfort, D., Hillier, D. 2006. Corporate social responsibility and the UK construction industry. Journal of corporate real estate, 8(3), 134-150. DOI: $10.1108 / 14630010610711757$

Jones, T., Shan, Y., Goodrum, P. M. 2010. An investigation of corporate approaches to sustainability in the US engineering and construction industry. Construction management and economics, 28(9), 971-983. DOI: 10.1080/01446191003789465

Kitson, A., Campbell, R. 1996. The ethical organisation. In The ethical organisation (p. 97117). Macmillan Education UK.

Kreps, T.J. 1940. Measurement of the social performance of business. In: An investigation of concentration of economic power for the temporary national economic committee (Monograph No. 7). U.S. Government Printing Office, Washington, DC.

Lawal, E., May, G., Stahl, B., 2017. The Significance of Corporate Social Disclosure for HighTech Manufacturing Companies: Focus on Employee and Community Aspects of Sustainable Development. Corporate social responsibility and environmental management. 24(4), 295-311. DOI: 10.1002/csr.1397. 
Lawrence, P.R., Lorsch, J.W. 1967. Differentiation and integration in complex organizations. Administrative science quarterly, 1-47.

López, M.V., Garcia, A. Rodriguez, L. 2007. Sustainable development and corporate performance: A study based on the Dow Jones sustainability index. Journal of business ethics, 75(3), 285-300. DOI: 10.1007/s10551-006-9253-8

Lu, J. W., Beamish, P. W. 2004. International diversification and firm performance: The Scurve hypothesis. Academy of management journal, 47, 598-609. DOI: 10.2307/20159604

Lu, W., Chau, K., Wang, H., Pan, W. 2014. A decade's debate on the nexus between corporate social and corporate financial performance: A critical review of empirical studies 20022011. Journal of cleaner production, 79, 195-206. DOI: 10.1016/j.jclepro.2014.04.072

Lu, W., Ye, M., Flanagan, R., Ye, K. 2015. Corporate social responsibility disclosures in international construction business: Trends and prospects. Journal of construction and engineering management, 04015053. DOI: 10.1061/(ASCE)CO.1943-7862.0001034

Lu, W., Yuan, H. 2013. Investigating waste reduction potential in the upstream processes of offshore prefabrication construction. Renewable \& sustainable energy reviews, 28, 804811. DOI: 10.1016/j.rser.2013.08.048

Margolis, J.D., Walsh, J.P. 2001. People and profits? The search for a link between a company's social and financial performance. Psychology Press.

Margolis, J.D., Walsh, J.P. 2003. Misery loves companies: Rethinking social initiatives by business. Administrative science quarterly, 48, 268-305. DOI: 10.2307/3556659

Mathews, M.R. 1993. Socially responsible accounting, Chapman Hall, London.

McGuire, J., Sundgren, A., Schneeweis, T. 1988. Corporate social responsibility and firm financial performance. Academy of management journal, 31, 854-872. DOI: $10.2307 / 256342$

Mikami, K. 2011. Enterprise forms and economic efficiency. Abingdon: Routledge. 
Moeller, S.B., Schlingemann, F.P., Stulz, R.M. 2004. Firm size and the gains from acquisitions. Journal of Financial Economics, 73(2), 201-228. DOI: 10.1016/j.jfineco.2003.07.002

Moore, M.H. 2000. Managing for value: Organisational strategy in for-profit, nonprofit, and governmental organisations. Nonprofit and voluntary sector quarterly, 29(1), 183-208. DOI: $10.1177 / 0899764000291 S 009$

MSCI Inc. 2015. Industry report: Construction \& engineering. New York.

Murray, M., Dainty, A. 2008. Corporate social responsibility: Challenging the construction industry. In Corporate social responsibility in the construction industry, M. Murray, and A. Dainty (eds). Taylor \& Francis: London: 3-23.

Ngowi, A., Pienaar, E., Talukhaba, A., Mbachu, J. 2005. The globalisation of the construction industry $-\mathrm{a}$ review. Building and environment. 40(1), 135-141. DOI: 10.1016/j.buildenv.2004.05.008

Orlitzky, M., Schmidt, F. L., Rynes, S.L. 2003. Corporate social and financial performance: A

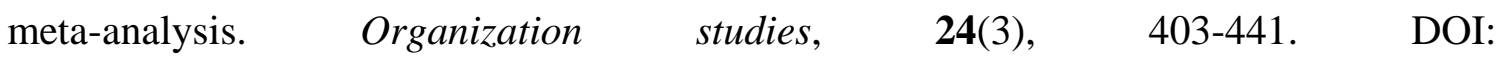
$10.1177 / 0170840603024003910$

Painter-Morland, M. 2006. Triple bottom-line reporting as social grammar: Integrating corporate social responsibility and corporate codes of conduct. Business ethics: A European review, 15(4), 352-364. DOI: 10.1111/j.1467-8608.2006.00457.x

Pala, A. 2013. Structural breaks, co-integration, and causality by VECM analysis of crude oil and food price. International Journal of energy economics and policy, 3(3), 238.

Pearce, D. 2003. Environment and business: socially responsible but privately profitable? The challenge of change: fifty years of business economics, 54-65.

Petrovic-Lazarevic, S. 2008. The development of corporate social responsibility in the Australian construction industry. Construction management and economics, 26(2), 93-101. DOI: $10.1080 / 01446190701819079$ 
Porter, M.E., Kramer, M.R. 2006. Strategy and society, the link between competitive advantage and corporate social responsibility. Harvard business review, 85(12), 78-92.

Porter, M.E., Kramer, M.R. 2011. Creating shared value. Harvard business review, 89(1/2), $62-77$.

Schons, L., Steinmeier, M. 2016. Walk the Talk? How symbolic and substantive CSR actions affect firm performance depending on stakeholder proximity. Corporate social responsibility and environmental management, 23, 358-372. DOI: 10.1002/csr.1381

Snell, R.S., 2000. Studying moral ethos using an adapted Kohlbergian model. Organization studies, 21(1), 267-295. DOI: 10.1177/0170840600211006

Vallaster. C. 2017. Managing a company crisis through strategic corporate social responsibility: a practice-based analysis. Corporate social responsibility and environmental management, 24, 509-523. DOI: 10.1002/csr.1424

Wagner, M. 2009. Innovation and competitive advantages from the integration of strategic aspects with social and environmental management in European firms. Business strategy and the environment, 18, 291-306. DOI: 10.1002/bse.585

Wang, H., Choi, J., Li, J. 2008. Too little or too much? Untangling the relationship between corporate philanthropy and firm financial performance. Organization science, 19(1), 143159. DOI: $10.1287 /$ orsc. 1070.0271

Wang, H., Lu, W., Ye, M., Chau, K., Zhang, X. 2016. The curvilinear relationship between corporate social performance and corporate financial performance: Evidence from the international construction industry. Journal of cleaner production, 137, 1313-1322. DOI: 10.1016/j.jclepro.2016.07.184

Ward, H., Smith, C. 2011. CSR at a Crossroads: Futures for CSR in the UK to 2015. Russell Press, London. 
Weintraub, R. 2007. Neoclassical Economics. The concise encyclopaedia of economics. Retrieved September 26, 2010.

Williamson, O.E. 1991. Comparative economic organisation: The analysis of discrete structural alternatives. Administrative science quarterly, 269-296.

Zaheer, S., 2002. The liability of foreignness, redux: A commentary. Journal of international management, 8(3), 351-358. DOI: 10.1016/S1075-4253(02)00070-4 
Table 1 Excerpt from the panel data

\begin{tabular}{|c|c|c|c|c|c|c|c|c|}
\hline \multirow{2}{*}{ Firm } & \multirow{2}{*}{ Country } & \multirow{2}{*}{ Indicator } & \multicolumn{6}{|c|}{ Year } \\
\hline & & & 2006 & 2007 & 2008 & $\ldots$ & 2014 & 2015 \\
\hline \multirow[t]{4}{*}{ ACS } & Spain & CSR $(? / 10)$ & 6.45 & 6.24 & 6.24 & $\ldots$ & 3.70 & 3.30 \\
\hline & & LnREV & 9.77 & 9.95 & 10.07 & $\ldots$ & 10.74 & 10.52 \\
\hline & & $\mathrm{D} / \mathrm{E}$ ratio & 3.45 & 1.98 & 1.38 & $\ldots$ & 2.51 & 2.07 \\
\hline & & LnMC & 9.88 & 9.92 & 9.59 & $\ldots$ & 9.31 & 9.13 \\
\hline \multirow[t]{4}{*}{ Caterpillar } & U.S.A. & CSR (?/10) & 3.38 & 4.73 & 4.87 & $\ldots$ & 5.70 & 6.00 \\
\hline & & LnREV & 10.63 & 10.71 & 10.85 & $\ldots$ & 10.92 & 10.76 \\
\hline & & $\mathrm{D} / \mathrm{E}$ ratio & 3.98 & 3.20 & 5.29 & $\ldots$ & 2.33 & 2.56 \\
\hline & & LnMC & 10.59 & 10.74 & 10.20 & $\ldots$ & 10.92 & 10.59 \\
\hline \multirow[t]{4}{*}{ JGC } & Japan & CSR $(? / 10)$ & 4.66 & 4.53 & 4.53 & $\ldots$ & 3.50 & 3.00 \\
\hline & & LnREV & 8.56 & 8.48 & 8.41 & $\ldots$ & 8.90 & 8.90 \\
\hline & & $\mathrm{D} / \mathrm{E}$ ratio & 0.11 & 0.09 & 0.11 & $\ldots$ & 0.09 & 0.09 \\
\hline & & LnMC & 8.34 & 8.26 & 7.95 & $\ldots$ & 8.52 & 8.24 \\
\hline
\end{tabular}

Note: 1 . LnREV is the nature logarithm of revenue; D/E ratio is debt/equity ratio; LnMC is the nature logarithm of market capitalization; 2. D/E ratio is the ratio with no units, LnMC and LnREV are also with no units; 3. the measure for CSR is between 0 and 10 . 
Table 2 ADF unit root test

\begin{tabular}{|c|c|c|c|c|c|}
\hline & Variables & Method & t-statistic & p-value & Results \\
\hline \multicolumn{6}{|l|}{ Level -I(0) } \\
\hline \multirow{3}{*}{$\begin{array}{l}\text { CFP (Dependent } \\
\text { variable) }\end{array}$} & \multirow[t]{3}{*}{ LnREV } & None & 79.23 & 1.0000 & Non-stationary \\
\hline & & Constant & 205.99 & 0.0001 & Stationary \\
\hline & & Trend & 207.55 & 0.0000 & Stationary \\
\hline \multirow{3}{*}{$\begin{array}{l}\text { CSR } \\
\text { (Independent } \\
\text { variable) }\end{array}$} & \multirow[t]{3}{*}{ CSR } & None & 106.00 & 0.9645 & Non-stationary \\
\hline & & Constant & 190.30 & 0.0010 & Stationary \\
\hline & & Trend & 204.58 & 0.0001 & Stationary \\
\hline \multirow{2}{*}{$\begin{array}{l}\text { Control } \\
\text { Variables }\end{array}$} & $\mathrm{D} / \mathrm{E}$ ratio & Trend & 248.43 & 0.0000 & Stationary \\
\hline & LnMC & Trend & 225.55 & 0.0000 & Stationary \\
\hline \multicolumn{6}{|l|}{$I^{s t}$ Difference $-I(1)$} \\
\hline \multirow[t]{3}{*}{ CFP } & \multirow[t]{3}{*}{ LnREV } & None & 550.02 & 0.0000 & Stationary \\
\hline & & Constant & 328.58 & 0.0000 & Stationary \\
\hline & & Trend & 251.37 & 0.0000 & Stationary \\
\hline \multirow[t]{3}{*}{ CSR } & \multirow[t]{3}{*}{ CSR } & None & 616.09 & 0.0000 & Stationary \\
\hline & & Constant & 338.64 & 0.0000 & Stationary \\
\hline & & Trend & 176.36 & 0.0000 & Stationary \\
\hline
\end{tabular}

Notes: 1. LnREV is the nature logarithm of revenue; D/E ratio=debt/equity ratio; LnMC is the nature logarithm of market capitalization. 2. Alternative hypothesis of test is stationarity. 
Table 3 Johansen test for co-integration

\begin{tabular}{ccccc}
\hline $\begin{array}{c}\text { Hypothesised } \\
\text { No. of CE(s)** }\end{array}$ & Trace Statistics & p-value & $\begin{array}{c}\text { Max-Eigen } \\
\text { Statistics }\end{array}$ & p-value \\
\hline None & $446.8^{*}$ & 0.0000 & $405.5^{*}$ & 0.0000 \\
\hline At most $\mathbf{1}$ & $184.3^{*}$ & 0.0000 & $184.3^{*}$ & 0.0000 \\
\hline
\end{tabular}

*indicates the test statistics are significant at the $1 \%$ level

$* * \mathrm{CE}=$ cointegration eqn(s), denotes rejection of the hypothesis at the 0.05 level

Trace test and max-eigenvalue test indicate 2 cointegration eqn(s) at the 0.05 level 
Table 4 Granger causality test by VECM

\begin{tabular}{lllll}
\hline \multicolumn{2}{c}{ Dependent Variable } & $\Delta$ LnREVit & & \\
\hline \multicolumn{1}{c}{ Variable } & Coefficient & Std. Error & t-statistic & p-value $^{(\mathbf{2})}$ \\
\hline ECT $^{(\mathbf{1})}$ & $-0.0947(\mathrm{c}(1))$ & 0.0149 & -6.3357 & $0.0000^{* * *}$ \\
\hline$\Delta$ CSR (it-1) & $-0.0237(\mathrm{c}(3))$ & 0.0130 & -1.8270 & 0.0681 \\
\hline Wald Test $^{(\mathbf{3})}$ & & Value=3.3379 & \\
\hline R-squared $^{(\mathbf{4})}$ & & & $\mathbf{0 . 0 6 7 7}$ \\
\hline Adjusted R-squared & & & 0.2239 \\
\hline Durbin-Watson Stat & & & 0.1944 \\
\hline
\end{tabular}

Notes: (1) ECT represents the error correction term. (2) P-value of the estimates is reported in brackets. ', *, **, *** indicates significance at the $0.1,0.05,0.01,0.001$ levels, respectively. (3) Wald test is for the coefficient of $\Delta \mathrm{CSR}_{\mathrm{it}-1}$, the null hypothesis is $\mathrm{c}(3)=0$. (4) Control variables are included in this model which are not shown. The total number of observations is 822 . 
Table 5 Short and long run equilibrium

\begin{tabular}{|c|c|c|c|c|c|c|}
\hline \multirow{2}{*}{ Equilibrium } & \multicolumn{3}{|c|}{$\triangle \mathrm{CSR}$ (it-1) } & \multicolumn{3}{|c|}{ ECT } \\
\hline & Coefficient & t-stat & p-value & Coefficient & t-stat & p-value \\
\hline Short run & -0.0238 & -1.8270 & 0.0681 & & & \\
\hline Long run & & & & -0.0947 & -6.3357 & $0.0000 * * *$ \\
\hline
\end{tabular}

